\title{
Anonymous: A Political Ontology of Hope
}

\author{
Garry Potter ${ }^{*}$
}

It is argued in this article that Anonymous is a kind of socio-political grouping hitherto unique in human history. It exists in a manner that in some respects is the very antithesis of a political grouping. It is not only that it is leaderless, amorphous, changing and radically extreme in terms of direct democratic procedure. These features have appeared before on the historical political landscape. But the internet, and Anonymous's relationship to it, present them with a unique potential for future revolutionary political action. Whether they will realize this potential is not certain. But Anonymous is still evolving. Their social and political evolution is traced through its various stages to ground some very hopeful speculation as to their, and our, future. [Article copies available for a fee from The Transformative Studies Institute. E-mail address: journal@transformativestudies.org Website: http://www.transformativestudies.org (C2015 by The Transformative Studies Institute. All rights reserved.]

KEYWORDS: Anonymous, Hacker, Hactivist, Hope, Ontology.

Imagine if computer hackers, the daredevils of the networked world, suddenly became principled political activists; if they had a mission besides breaking and entering; if they had more to prove than that they are smarter than whoever designed your computer system, if their targets were selected as part of well organized, thoroughly researched, international human rights campaigns. (Naomi Klein, 1998)

\footnotetext{
* Garry Potter, Ph.D., is an Associate Professor at Wilfrid Laurier University. He has made two feature length documentary films Whispers of Revolution and Dystopia: What is to be done? He is also author of the book Dystopia. In addition, he is the author of two other books: The Bet: Truth in Science, Literature and Everyday Knowledges and The Philosophy of Social Science: New Perspectives, as well as numerous scholarly articles. He was also co-editor of the book After Postmodernism. Currently he is producing a series of educational films about classical sociological theory for Insight Media. Address correspondence to: Garry Potter, Wilfrid Laurier University, 1402 - 57 Queen Street North, Kitchener, CANADA N2H 6T7; e-mail: garrypotter34@aol.com.
} 